\title{
Localization, quantization and interaction with host factors of endogenous HTLV-1 HBZ protein in infected cells and ATL
}

\author{
Goutham U Raval', Carlo Bidoia', Greta Forlani ${ }^{1}$, Giovanna Tosi ${ }^{1}$, Antoine Gessain ${ }^{2}$, Roberto S Accolla ${ }^{1 *}$ \\ From 17th International Conference on Human Retroviruses: HTLV and Related Viruses \\ Trois llets, Martinique. 18-21 June 2015
}

Human T cell Lymphotropic Virus type 1 (HTLV-1) is the etiological agent of a severe form of neoplasia designated Adult $T$ cell Leukemia/Lymphoma (ATLL) It is widely accepted that the viral transactivator Tax-1 is the major viral product involved in the onset but not in the maintenance of neoplastic phenotype as only $30-40 \%$ of ATLL cells express Tax-1. It has been recently demonstrated that HBZ (HTLV-1 bZIP factor), a protein encoded by the minus strand of HTLV-1 genome, constantly expressed in infected cells and in ATLL tumor cells, is also involved in the pathogenesis of leukemia. The full role played by HBZ in oncogenesis is still to be explored in detail mainly owing to the unavailability of tools to assess quantitative expression, subcellular location and interaction of HBZ with host factors in ATLL. By the use of the first reported monoclonal antibody against HBZ, 4D4-F3, generated in our laboratory it has been possible to carefully assess for the first time the above parameters in HTLV-1 chronically infected cells and, most importantly, in leukemic cells from patients. Endogenous HBZ is expressed in speckle-like structures localized in the nucleus. The calculated number of endogenous HBZ molecules varies between 18.000 to 36.000 molecules per cell, 22-44 fold less than the amount expressed in HBZ transfected cells used by most investigators to assess the expression, function and subcellular localization of the viral protein. HBZ interacts in vivo with p300 and JunD and co-localizes only partially, and depending on the amount of expressed HBZ, not only with p300 and JunD but also with CBP and CREB2.

\footnotetext{
* Correspondence: accolla.roberto@gmail.com

'Department of Surgical and Morphological Sciences, University of Insubria, Varese, Italy

Full list of author information is available at the end of the article
}

The possibility to study endogenous HBZ in detail may significantly contribute to a better delineation of the role and presence of HBZ during HTLV-1 infection and cellular transformation.

\section{Authors' details}

'Department of Surgical and Morphological Sciences, University of Insubria, Varese, Italy. ${ }^{2}$ Departement de Virologie, Institut Pasteur, Paris 75015, France.

Published: 28 August 2015

doi:10.1186/1742-4690-12-S1-P43

Cite this article as: Raval et al:: Localization, quantization and interaction with host factors of endogenous HTLV-1 HBZ protein in infected cells and ATL. Retrovirology 2015 12(Suppl 1):P43.

Submit your next manuscript to BioMed Central and take full advantage of:

- Convenient online submission

- Thorough peer review

- No space constraints or color figure charges

- Immediate publication on acceptance

- Inclusion in PubMed, CAS, Scopus and Google Scholar

- Research which is freely available for redistribution 